\title{
Arms Trade As Instrument Of Insecurity In Nigeria
}

\author{
Charas Madu Tella \\ Department of Political Science, \\ Federal University Dutse, Jigawa State \\ Shehu M. Liberty \\ Department of Public Administration \\ University of Maiduguri. \\ Muritala Babatunde Hassan \\ Department of Political Science, \\ Federal University Dutse, Jigawa State
}

\begin{abstract}
Nigeria in recent years has witnessed continued escalation of acts of insecurity. Insurgency, civil violence, kidnapping, militancy, ethnic/religious clashes, allegedly to have been caused by injustice, intolerance, poverty, unemployment, extremism, corruption, ill education and poor governance, have been on the increase in the country. This is not unconnected with the prevalence issue of illegal arms trade and proliferation of small arms and light weapons in the country. Arms are regarded as small weapons that are harmful and dangerous to human existence, they include revolvers, pistol, riffles, sub-machine guns, mounted grenade launchers, while the light weapon refers to heavy machine guns, hand held under-barred portable anti-aircraft missile system. It is on this premise that this study examines the relationship between the spate of insecurity in Nigeria and arms trade. In doing this, the authors used primary and secondary sources of data using chi-square techniques to analyze the data. A total of 300 questionnaires were produced, distributed, retrieved and analyzed. The findings revealed, among other things, that terrorism, conflicts and violence have posed serious threat to national development. As such, it was recommended that government should take a decisive action to prosecute any person found in possession of any arms, irrespective of political affiliation.
\end{abstract}

Keywords: arms trade, armed violence, smuggling, arms control

\section{INTRODUCTION}

War is the most recurrent spectacular phenomenon of human existence and background of all civilizations. It can be regarded as a vehicle of change, destructive, constructive as well as civilization. Despite its importance in human history, there is no general theory of war. However, war could be regarded as a legal condition which brings two or more hostile groups together to fight by arms. It is also regarded as the act of violence intended to compel opponent to submission. In Nigeria, there had been series of wars, violence and conflicts. Example, the Maitatsine religious crises in Kano in 1981, Maiduguri 1982, Yola and Gombe 1983, the Billiry/Kaltungo crises, the Modakeke crises, the ethnic Ijaw/Itsekiri in the 1980s, Hausa/Yoruba conflicts in Lagos, protest on the imposition of Shariah across Northern Nigeria in 2001, Muslims/Christains conflicts in 2001 in Jos and Kano ethnic clashes in Warri, Delta State in 2002, Zangon Kataf crises, Tiv/Jukun crises. Others are contemporary wars were the Fulani Headsmen in Benue, Enugu, Jos, Yola, Enugu, Nasarawa, Boko-Haram crises, the Niger Delta Avenger, MEND, IPOB etc. 
These crises in most cases were prosecuted using small and light weapons and most of which were illegally acquired through illegal means and black marketeering and smuggling. The proliferations of these small arms and light weapons in Nigerian and her immediate environs countries such as Benin, Cameroon, Chad, Niger, could be concluded as the most immediate or the most remote causes of insecurity. Consequently, this provided potential grounds for fueling armed robbery, ethno/religious, assassinations, insurgencies, kidnapping and other criminal terrorist acts and violence posing threat to Nigerian co-existence. Some of this little violence metamorphosed to larger civil wars and insurgency as currently obtained in part of this country.

This destabilized the country as well as the entire West Africa economically, political, socially. It also assisted greatly in forcibly killing and displacing thousands and millions of civilians across the regions. More so, after the conflicts some of these arms often remain in circulation in the hands of unscrupulous peoples and groups which may lead to violence sometimes somewhere. While, in non-conflict areas, these small arms may be used to perpetrate homicide, suicide and accidents.

It is against this development that smuggling of arms into Nigeria has continued to undermine good governance and disrupts trade, tourism and investment, economic development and generally puts democracy and development at risk. It heightens inter-state conflicts such as Benue and Nasarawa, Benue and Taraba and put the country itself under attack. With armed guerrilla, ethnic militias groups proliferating and often dividing into warring factions, internal instabilities increasingly tend to evolve into larger regional wars. Cross-border support for insurgent movements is also on the rise in Nigeria- Cameroon, Nigeria-Chad, Nigeria-Niger, Nigeria-Benin Republic. Large-scale wars are ongoing in these boarder areas resulting in millions of internally displaced persons. Malam (2014:12) opined that:

After the end of cold war, these arms in circulation lost their way into the hands of illegal arms dealers, security entrepreneurs, ethnic militia groups, private military companies, and local smugglers there by fueling on-going wars and facilitating the commencement of new ones in Africa. Also, the accelerated pace of globalization in the same period facilitated both legal and illegal cross-border transfers of these weapons, while a sudden upsurge in intra-state conflicts created an overwhelming demand for the SALW, thereby making them weapons of choice in majority of recent conflicts and in non-war settings such as sectarian violence (ethnic, religious and chieftaincy conflicts), suicides, murders, homicides and accidents.

According to Ayissi, Anatole \& Ibrahim (2005), there are more than hundred (100) million illegally smuggled small arms and light weapons representing about $0.8 \%$ small arms and light weapons in circulation. This has contributed to the escalation of displacement of people, organized crimes, terrorism, insurgency and violence. The proliferations of these small arms are at the high increase paving ways to the new emerged trends of violence and organized crimes as currently obtained. The situation has led to the growing, in geometric progression, all forms of violent acts, which possesses a serious threat and challenges to not only Nigeria but also West Africa as whole.

The implications of this arms race and smuggling forced Nigeria to join and became a member nations tasked with the responsibility of prohibiting the transfer of conventional weapons to countries allegedly intended to commit or facilitate genocide, crimes against humanity or war crimes. 
Other reasons are to ensure strict control of the international race in conventional arms. It was against this backdrop that in 2013, Nigeria signed a ratification of the landmark global Arms Trade Treaty (ATT) committed to the values of the Arms Trade Treaty and to ensure that small arms and light weapons are appropriately transferred and access denied to terrorist groups, pirates, bandits etc. Omolade (2013) opined that this singular act has solidified Nigerian's role as a continental peace keeper, intent on addressing the problem of arms from its root.

\section{Research Design}

\section{METHODOLOGY}

The descriptive survey method was adopted for this study. The study seek to observe, assess and explore correlation between Arms trade, proliferation of small arms, light weapons and insecurity in Nigeria especially, Boko-Haram insurgency in the North-east part of Nigeria.

\section{Population for the Study}

The estimated population for this study is three hundred (300) respondents drawn from among immigration officers, department of peace conflicts in the university and security expert analyst. The breakdown of the population is illustrated in table below.

\begin{tabular}{|l|c|c|}
\hline \multicolumn{1}{|c|}{ Level of Study } & Population & Percentage Population \\
\hline Immigration Department & 98 & $32.66 \%$ \\
\hline Security expert analyst & 65 & $21.66 \%$ \\
\hline Department of Peace \& conflict studies & 137 & $45.66 \%$ \\
\hline Total & 300 & $100 \%$ \\
\hline
\end{tabular}

\section{Sample and Sampling Technique}

Due to the small number of respondents involved, the entire population of the study was used as the sample.

\section{Hypotheses}

1. Ho: The security threat, leading to death, rape, assault, displacement of people in Nigeria is not attributed to poorly regulated trade arms and ammunitions.

$\mathrm{H}_{1:}$ The security threat, leading to death, rape, assault, displacement of people in Nigeria is attributed to poor trade arms and ammunitions regulations

2. Ho: Sales, Smuggling, gift, trade, race of arms to Nigerians is not attributed to loopholes and the long boarder size.

3. $\mathrm{H}_{1}$ : Sales, Smuggling, gift, race of arms to Nigerians is attributed to long border size across Nigeria

\section{Conceptual clarification}

Nigeria, like other countries of the world, has consistently considered arms trade as one of the major problems facing humanity today. Despite its importance, arms race has been described as the highest form of political disorder that has so far been developed and sustained. Throughout history of states, each has been insured by the existence of the other, and the action in each in pursuit of its own national security having frequently combined with those of the others to produce wars. Given the power of man's military technology, war is now the most prominent and greatest threat to the community of mankind. Since international and national security lies at the root of war, addressing it is a matter of acknowledged importance and political will. Therefore, small arms and light weapons means any man-made portable lethal weapon that expels or launches, is designed to expel or launch, or may be readily converted to 
expel or launch a shot, bullet or projectile by the action of an explosive, including antique small arms and light weapons or their replicas.

The most obvious impact of military technology on international level is the phenomenon that is widely but often inaccurately referred to as "Arms Trade". The term suggests a selfstimulating military rivalry between states in which their efforts posed threat to each other (Buzan1987). In other words, given the political condition of anarchy, states are vulnerable to a type of competition with each other in which military technology is major independent variables. The evolution and development of arms race in Nigeria and indeed other African countries play prominent roles in the military advancement. However, arms trade created problems between individuals, groups, states looking for domination. According to the United Nation (UN) (2014:9)

The need for the Arms Trade Treaty remains abundantly clear. Deadly weaponry continues to find its way into irresponsible hands. Unscrupulous arms brokers defy United Nations arms embargoes. Ruthless leaders turn their arsenals on their own citizens. Ammunition depots are poorly guarded. State-owned weapons go missing. Civilian airplanes end up in the crosshairs ... Pirates wield grenade launchers and machine guns against merchant ships. Drug traffickers outgun police forces ... In adopting the Arms Trade Treaty, Member States came together to support a robust, legally binding commitment to provide a measure of hope to millions of people around the world.

\section{OBJECTIVES OF THE ARMS TRADE}

i. States should be transparent in arms transfer states, whether producers or importers, they should seek to ensure that their level of armaments is commensurate with their legitimate self-defense and security requirements.

ii. States receiving arms have an equivalent responsibility to seek to ensure that the quantity and level of sophistication of their arms imports are commensurate with their legitimate self-defense and security requirements and that they do not contribute to instability and conflict in their regions.

iii. Arms producing or supplier States have a responsibility to ensure that the quantity and level of sophistication of their arms exports do not contribute to instability and conflict in their regions.

iv. States should recognize the responsibility to prohibit and eradicate illicit arms trafficking and the need for measures to achieve this end, taking into account the inherently clandestine nature of this traffic.

v. Lastly, economic factor should not be the only factors in international arms transfers. Other factors are peace and security and efforts aimed at promoting social and economic development, preventing arms races and achieving disarmament under effective international control.

\section{Arms Trade and Insecurity in Nigeria}

The contemporary armed conflict in Nigeria and across the globe can be considered as the main causes of human terrorism, violence, conflicts and displacement. According to the World Bank (2014), nothing undermines investment climates as much as armed insecurity. Investment is discouraged in conflict-ridden countries experiencing high levels of violence. This leads to a decrease in in-coming investment, which disrupts development in these countries, and therefore can aggravate poverty and inhibit access to social services. In 2006 the Geneva Declaration on Armed Violence and Development recognized armed violence as both a cause and consequence of terrorism. To U.N. Doc A/Res/64/48 (2010:3): 
The global trade in conventional arms is as old as the history of war, and plays a major role in global politics. Arms trade can be both legal and illegal. A persistent issue regarding legal arms trade, especially the trade of small arms and light weapons, is that it can nevertheless contribute to human rights abuses and violations of humanitarian law.

Terrorism and other related violent activities are consequences of poor governance. Cronin (2011) opined that: "The current wave of international terrorism, characterized by unpredictable and unprecedented threats from non-state actors is not only a reaction to terrorism but also facilitated violence .In other words, terrorism and other related violent activities such as Boko-Haram insurgency are consequences of corruption and unemployment. Cronin (2011) further concluded his views that:

the gap between the rich and poor countries have expanded over the last 20 years owing to the effects of international terrorism, thereby fuelling animosities and violence among the poor, marginalized countries predominately located in the Third World countries that are against the pioneer of Western policies. Cronin thus concluded that this results in aggression in the form of terrorism in the Third World against the pioneers of these policies that disarticulates their economy and leaves them with nothing.

This means, terrorism can be linked to the theory of deprivation and as a manifestation of conflict. According to Paul Martin, Canadian Minister of Commerce, the September 11, 2001 terrorist attack was aimed at to destabilizing USA economy and which they did. He concluded by saying that:

For the terrorist, however, the aim of their criminal act was not only the destruction of life; they were seeking to destroy our way of life. The terrorist did not choose their target randomly. New York's World Trade Center stood at the heart of the international financial district. It was a symbol of accomplishment and confidence. It was targeted for that reason. The terrorist sought to cripple economic activity, to paralyze financial relations, to create new barriers between economics, countries and people

Supporting the above statement, Caleb Olubolade, cited by Abimbola, and Adesote, (2012) opined thus: "I will rather say that we are facing new threats different from what we used to face before the 1960s" and concluded thus "these threats confront us, we will find solutions to them; it is now a period to look forward and overcome the challenges that face us." The dimensions have contributed to national security threat engendered by the process of globalization that is capable of disintegrating the country. William, (2006) and Aydinli, (2008), in their opinion stated that these terrorists and insurgency groups have become more powerful than the Nigerian security. This threat has been exemplified by the September 11, 2001 as pointed out by Duru and Ogbonnaya, (2010). They elaborated that the bombing of the World Trade Centre (WTC) in the United States by the Al-Qaeda terrorist network served as an emerging trend. The attacks have resulted in the killings of hundreds of people, rendered more than a million people homeless and destroyed over \$billions of worth of properties. They further observed that:

What should be understood about terrorists method of operation is that any evil doer will look for a justifying reason, whether tenable or untenable, to indulge in evil deed. And the reason often given is one which appeals to people of like minds at least in the neighborhood. This is to elicit their sympathy and support. The common denominator among all terrorists is the theory of using what you have to get what you want. 


\section{Factors Enhancing Arms Smuggling in Nigeria}

The Arms Trade Treaty (ATT) is the first international legally binding agreement to establish standards for regulating the trade in conventional arms and preventing the illicit trade in weapons. The United Nations negotiating process that led to the ATT began in 2006 and ended in April 2013, when the UN General Assembly adopted the text of the treaty. The process was supported by a coalition that brought together predominantly arms exporting states with states that primarily import arms or act as transit states. Nigeria became member nation prohibiting arms trade and smuggling. The implications of arms trafficking have a profound impact on peace and security in the country.

According to (Musa, 2002; Bah, 2004; Badmus, 2009) proliferation of arms promotes violent crime; workers" revolts; subversion; sabotage; religious crises; enhances conflicts between communities; social agitation; micro-nationalism (ethnic conflicts); insurrection; and terrorism. Similarly in line with the above, Adebayo (2012) the different causes of small arms proliferation in Nigeria can largely be attributed to smuggling and illegal trade, corruption and inadequate manpower to man our boarders. Supporting the above position, Hazen and Horner (2007:37) equally observed that:

There are so many small arms smuggling into the country. The major problem associated to smuggling was that the exact entrance routes of these weapons are not clearly known or defined. This could be attributed to the boarder size of the country as well as other entry points such as airports, seaports, which makes it difficult to tract all the cross-border trade for the purposes of monitoring and evaluation.

According to a National Population Commission's publication (2006), Nigeria has about 1500 kilometers of shared land border with the Niger and Chad in the North and about 1000 kilometers land border with Benin in the West (Ginifer \& Ismail, 2005:5).In the Eastern side, about 1700kilometers land marks border with Cameroun. This makes it difficult if not impossible to effectively man such extensive borders.

Other factors facilitating smuggling of small and light weapons in Nigeria are inadequate staff, good funding and lack of modern surveillance equipment as rightly observed by Yacubu, (2005). Furthermore, a number of transit routes for cross-border arms trafficking have been identified. For example, the Cameroon is bordered to Nigeria through Tetewa, Bosso and Tudun Mota. Chad is through Gambaru Ngala, Mobbar while Cameroon is through Kirawa and Banki in Bama and Gwoza local government areas respectively. Furthermore, Niger is bordered with Nigeria through Maigatari in Katsina,Nguru in Yobe and Mallam Fatori in Borno State.In the South-West Nigeria are Seme border in Lagos and the Igbobila-Ilaro-Lagos route and Idi-Iroko, in Ogun State.

Khakee (2003) in his contribution stated that smugglers from Gabon and Cameroun use highspeed boats to smuggle arms from other West African and Central African countries. Today, due to smuggling, small and light weapons are found common in the hands of terrorists. Nigeria in the last six months, apart from Boko-haram insurgency, has witnessed series of terrorist acts and destructions in the Niger Delta region.

In addition, there are also local gun productions areas in the country. For example, during the course of fighting the Boko-Haram insurgency, some individuals and groups suspected to be members of the sects were arrested in Jos, Kaduna, Gombe, Yola, and Maiduguri fabricating guns to the members. In Isolo market area of Lagos alone, there were four blacksmiths and all of them were involved in forging local guns of various shapes and sizes. In fact one of them confessed that he along with other blacksmiths were responsible for producing some of the arms used by the Odua People"s Congress (OPC), an armed group in Nigeria ( TELL, 6 Aug., 2001) 


\section{Theft of Arms}

The theft of weapons is a major source of arms proliferation and organized crime in Nigeria. (Yacubu, 2005), opined that between 1998 and 2000, about 196 weapons were registered as "lost" by the Nigerian police. In Owerri, the Customs Armory was broken and a large quantity of arms ammunitions and were carted away by some gun men. Again, quite a large number of military arms were reported missing or stolen more especially in the north-east region taken away by the Boko-haram sects. Today, more than $80 \%$ of the Boko-Haram fighting equipment is either confiscated from the security personnel while the remaining were either brought into the country through smuggling, stole or illegally bought from the military personnel themselves. For example, in the last 6 years of fighting insurgency in the north-east, there was not a single of barrack or police stations not attacked by the Boko-Haram. Collier (2009:115) stated that:

Terrorist group attacks and theft of weapons from stations in the North-East region of Nigeria are cases where legally acquired arms subsequently fall into the hands of nonstate actors who us them for nefarious purposes.

Another method used in the smuggling of arms was through using hidden improvised compartments in a vehicle designed to avoid detection by security agents. In areas like Mobbar and Jigawa which shares boarder with Niger, cars are used for such operations with constructed chambers for concealing arms or additional fuel tank to minimize the rate of refueling. This can also be identified in the Niger Delta which quite a number of the Militant allegedly specialized in buying arms in Bakassi Peninsula for supply to Boko Haram insurgents. Most of this the traffickers used special Tank constructed for concealing arms for shipment to the north. The use of tunnels to traffic arms, drugs and other substances is not a new tactics among terrorist groups as done by the Palestinians to ship arms and control ban materials. Taking this advantage, the Boko Haram also constructs such tunnels for arms trafficking, especially in Borno and part of Yobe state boarded with Niger, Chad and Cameroon.

\section{Black Marketeering and Illegal Arms Trade}

This is also another source of illegal arms in Nigeria as it was estimated that there are between 1-3 million small arms and light weapons in circulation in Nigeria. For example, the interception of containers loaded with pump action guns on the $25^{\text {th }}$ September, 2017 by the Nigeria Customs Service brings to the fore once more the implications of smuggling of dangerous weapons to the country's National Security. It is important to note that, these incidents are just the tip of the iceberg as; about eighty percent of smuggled weapons reportedly pass undetected. It is important to note that, on the spectrum of threat assessment based on gravity and risk potentials, proliferation of dangerous weapons is high on the scale. Nigeria is believed to be a popular destination for dangerous weapons on account of several reasons. The most prominent is, poor border control.

According to Jennifer and Jonas (2007) these posed a significant threat to peace and stability and that the majority of these small arms are illegally possessed, smuggled, traded in spite of the highly restrictive national laws regarding possession. Therefore effective border management is vitally important for the preservation of national security. This is why Spencer noted that "the border is the first line of defense against terrorism and the last line of a nation's territorial integrity". It is against this development that Boko Haram insurgency in northern Nigeria (especially the northeast zone) has been exacerbated by Nigeria's porous borders with Cameroon (1,690 kilometers) in the east, Niger (1,497 kilometers) in the north, Benin (773 kilometers) in the west, and Chad (87 kilometers) in the northeast. According to Freedom (2013), most of these border areas are either mountainous or in the jungle. Irrespective of their geographic nature, a common feature of the nation's borders is its porosity. 


\section{Armed Violence in Nigeria}

Today, it is news of a bomb blast. Yesterday, it was a suicide bombing, tomorrow; it may be an assassination and the day after, mass murder. Every day in Nigeria, the news seems to get from bad to worse, as put forward by Nadabo (2016) as the security situation deteriorates further and further. However, just a few years back we thought we were safe, and would not face security issues in our country. But now, there is Crises everywhere, with dying and properties being lost. The physical and physiological toll on Nigerians is great: Whenever there's a problem there's always the cause but the case becomes a bigger problem when the cause is not just one or two but an accumulation of national problems.

Armed violence in Nigeria, especially since 1999, has been escalating and is impoverishing and destabilizing communities. Jekada (2005) observed that unemployment and poverty that characterized the recent periods has led to a corresponding increase in violent crimes. Again, violent conflicts have been exacerbated and even intensified by violent actors with the tools which enable them to resolve conflicts violently through maiming and killing of innocent lives and also improve their socio-economic position by engaging in criminal activities. Violence in Nigeria is caused by severalfactors. They include scarce economic resources; politics and elections; the shift to democratic governance; the rise of armed groups; oil, ethnicity, religion and poverty.

This struggle for resources control has led to a broad sense of insecurity, opportunism, and the pursuit of self-help strategies across the country (Hazen \& Horner, 2007:6). According to Nnoli (2003), armed violence and its multi-dimensional consequences has been an obstacle to progress, political stability, economic prosperity and overall economic development of Nigeria. Violence provoked by conflicts, has often turned the peoples intention from creative production to creative destruction.

World Health Organization (2005) defined:

violence as the intentional use of physical force or power, threatened or actual, against oneself, another person, or against a group or community that either results in or has a high likelihood of resulting in injury, death, psychological harm,maldevelopment and deprivation

Armed violence in Nigeria has been a matter of great concern as the country is characterized by a lot of violent crimes and conflicts. Muggah (2001), rightly observed that the nature of armed violence tends to vary according to situational variables such as normative and behavioral culture, gender and demographics. This is particularly true for Nigeria considering the variations and frequency of armed communal, ethnic, religious, environmental and political conflicts that ravage the country. Again, Hazen and Horner (2007:52) have also pointed out that "While armed violence is not a rare occurrence in Nigeria, it is important to note that the country should not and cannot be viewed as homogenous in terms of criminality or security". Example, in Borno State which suffered much from the Boko-Haram terrorist acts than any other place, between 2011 and 2015, there were large number of people killed, injured and displaced.

\section{Impact of the Arms Trade}

The ATT Resolution noted that "the absence of international standards on the import, export and transfer of conventional arms is a contributory factor to terrorism, conflict, violence and the displacement of people, crime" and undermines peace, security and sustainable development. Similarly, the indiscriminate weapons sales foster political instability and human rights violations, prolong violent conflicts, and weaken diplomatic efforts to resolve differences peacefully especially in developing countries such as Nigeria. Irresponsible arms transfers have a negative impact on security and development for several reasons. Additionally, arms 
transfers contributed to the initiation or continuation of conflict. In the context of civil conflict, for instance, arms transfers can "enhance the capacity of the state.

\section{Lack of Adequate Control Mechanisms}

A number of regional and international instruments have been agreed since the Cold War that regulate or affect arms transfers. This raises the question: if there are instruments and initiatives in place seeking to secure similar objectives, why do we need an ATT? The answer is that existing instruments are proving insufficient or inadequate in tackling the illicit trade in conventional weapons and ensuring responsible transfers; the reasons for these inadequacies need to be considered so that an ATT does not repeat the same mistakes. This was raised by the Russian Federation in its submission:

It would be logical at the outset to analyze why the existing mechanisms are not sufficiently effective and precisely where they are encountering obstacles. This analysis must take place before the question of the formulation of a global instrument is raised

\section{Circulation of Small Arms}

There are an estimated seven to ten million illicit small arms and light weapons in West Africa (Small Arms Survey, 2003, p. 80). These figures are based on rough estimations, given population size and levels of conflict in countries and in the region as a whole. There are an estimated one million (Ebo, 2006, p. 1; Mensah, 2002) to three million (Obasi, 2002, p. 69) small arms and light weapons in circulation in Nigeria alone. Civilians possess the majority of weapons in the country. A 2001 estimate claimed that 80 per cent of the weapons in civilian possession had been obtained illegally (Obasi, 2002, p. 69), in spite of strict laws on civilian possession.

\section{DATA PRESENTATION AND ANALYSIS}

The following is the formula used to compute the information obtained from the field research using chi-square statistical methods;

Where formula for $\mathrm{x}^{2}=\sum(\mathrm{O}-\mathrm{E})^{2}$

$\mathrm{X}^{2}=$ chi - square

$0=$ observed value

$\mathrm{E}=$ expected value

$\mathrm{Df}=$ degree of freedom

Formula for expected value $(\mathrm{E})=$

Formula for $\mathrm{df}=(\mathrm{r}-1)(\mathrm{r}-1)$ at 0.05 level of significance

Table I Arms trade as instrument of insecurity

\begin{tabular}{|l|c|c|c|c|}
\hline variables & Agreed & Strongly agreed & Disagreed & Total \\
\hline Arms trade & 30 & 42 & 10 & 82 \\
\hline smuggling & 55 & 62 & 30 & 147 \\
\hline $\begin{array}{l}\text { Poor } \\
\text { governance }\end{array}$ & 20 & 30 & 13 & 63 \\
\hline
\end{tabular}


Table Ib

\begin{tabular}{|c|c|c|c|c|}
\hline 0 & $\mathrm{E}$ & $0-\mathrm{E}$ & $(0-\mathrm{E})^{2}$ & $\begin{array}{c}(0-\mathrm{E})^{2} \\
\mathrm{E}\end{array}$ \\
\hline 30 & 29.49 & 0.51 & 0.26 & 0.01 \\
55 & 52.85 & 2.14 & 4.58 & 0.09 \\
20 & 22.65 & -2.65 & 7.02 & 0.31 \\
42 & 37.63 & 4.37 & 19.10 & 0.51 \\
62 & 67.46 & -5.46 & 29.81 & 0.44 \\
30 & 28.91 & 1.09 & 1.19 & 0.41 \\
10 & 13.86 & -3.86 & 14.90 & 0.08 \\
30 & 20.34 & 9.66 & 93.31 & 4.59 \\
13 & 9.79 & 3.21 & 10.30 & 1.05 \\
\hline $\mathrm{X}^{2}$ & $=$ & & & 13.08 \\
\hline
\end{tabular}

$\mathrm{df}=(\mathrm{C}-1)(\mathrm{C}-1)(3-1)(3-1) 2 \times 2=4$

Decision at 0.05 level of significance $=9.488$

Therefore calculated value $=13.09$

Table value $=9.488$

The above analysis shows that there is a significant relationship between arms trade, smuggling and irresponsible sales of arms, and weapons to unscrupulous traders. Since the calculated value is more than the table value we accept the hypothesis and concluded that the hypothesis is accepted. This can be understood from the hiccups and challenges Nigeria have been facing in terms of arms trade and smuggling contributing to security challenges.

Table 2 poor policies

\begin{tabular}{|l|c|c|c|c|}
\hline variables & Agreed & Strongly agreed & Disagreed & Strongly disagree \\
\hline corruption & 37 & 43 & 6 & 6 \\
\hline inadequate staff & 52 & 66 & 10 & 7 \\
\hline Boarder mgt & 20 & 30 & 6 & 9 \\
\hline Total & 108 & 139 & 22 & 22 \\
\hline
\end{tabular}

Table 2b

\begin{tabular}{|c|c|c|c|c|}
\hline 0 & $\mathrm{E}$ & $0-\mathrm{E}$ & $(0-\mathrm{E})^{2}$ & $\begin{array}{c}(0-\mathrm{E})^{2} \\
\mathrm{E}\end{array}$ \\
\hline 37 & & & & 0.21 \\
52 & 34.34 & 2.66 & 7.08 & 0.05 \\
20 & 50.40 & 1.60 & 2.56 & 0.75 \\
43 & 24.26 & -4.26 & 18.15 & 0.01 \\
66 & 43.80 & -0.80 & 0.64 & 0.05 \\
30 & 64.26 & 1.74 & 3.03 & 0.03 \\
12 & 30.94 & -0.94 & 0.88 & 0.25 \\
17 & 13.86 & -1.86 & 3.46 & 0.55 \\
15 & 20.34 & -3.34 & 11.16 & 2.77 \\
\hline $\mathrm{X}^{2}$ & 9.79 & 5.21 & 27.14 & 4.67 \\
\hline
\end{tabular}

$\mathrm{df}=(\mathrm{C}-1)(\mathrm{R}-1)(3-1)(3-1) 2 \times 2=4$

at 0.05 level of significance $=9.488$

Decision - therefore calculated value $=4.67$

Table value $=9.488$

$\mathrm{H}_{0}=\mathrm{H}_{1}=\mathrm{H}_{2}-$ 
Therefore since the calculated value was 13.09 and the table value at degree of freedom of 4 , at 0.05 level of significance is 9.488 . The calculated value is greater than the table value. As such there is a significant relationship between the government policies and programmes such as size of the Nigerian boarders, inadequate staff, corruption which contributed to security threats, leading to death, rape, assault, displacement of millions of people around in Nigeria due to poorly regulated trade arms and ammunitions across the neighbor countries with Nigeria. To this end, we accept the hypothesis and concluded that corruption, inadequate manpower, funding etc have contributed to the smuggling of small arms and light weapons across Nigerian boarders.

\section{CONCLUSION}

The effort to fight terrorism and insurgency especially Boko-Haram and Niger Delta Militants had received widespread support by every Nigerians as well as neighboring countries through attempt to block illegal, diversion and smuggle of small and light weapons. Unfortunately, these efforts have not yielded good and anticipated result as there were still large traceable records of weapons being smuggled into the country. The insurgency in the North East from available intelligent is a major cause of inflow of smuggled weapons into the country, second only to the militancy in the Niger Delta in the last ten years. This was attributed to ineffective controlling mechanism, the long size boarder of Nigeria and the means of controlling the importation and distribution of small arms too.

Furthermore, the study also concluded that inadequate manpower, size of the Nigerian boarder, proliferation of small and light arms, corruption, inadequate modern surveillance equipment etc. However, the law enforcements agencies efforts to modernize their forces and to combat rising armed violence in the country are still a mirage. The efforts of the security forces to meet the demands of their roles in securing the country Individuals and groups in importing and purchasing small arms is still getting more difficult due to the draw of rich profits from the use of small arms in illegal activities. As such, the failure to effectively man border points known to be notorious routes for smuggling today represents the weakest link in our National Security infrastructure. These are the reasons why any strategy to curtail illegal arms circulation in the country must include, stringent control and checks on the weapons in the possession of security and law enforcement agencies

\section{RECOMMENDATIONS}

There is urgent need for Nigeria to strengthen its national and sub-regional mechanisms to combat the illicit trade in small arms and light weapons.

Government should reintroduce the disarmament program through declaration of amnesty to all Boko-Haram sects, ethnic militias, criminals and militants alike by rewarding them with jobs.

Nigerian Government should enforce the law on the control, regulate and prohibiting the transfer, manufacture and possession of small arms and light weapons in the country.

Governments must adhere to regional and international arms embargoes in order to prevent weapons from ending up in the hands of those prohibited from receiving them

ECOWAS should develop Small Arms Control Programme, and also encourage the establishment of national focal center charged with the responsibility of monitoring and investigating all ills regards arms transfer 
The United Nations should redouble its efforts to closely monitor compliance, supervise enforcement and suggest persuasive measures to enhance compliance.

Impunity under which arms brokers operate, States should adopt an international arms trade treaty, which would provide common international standards regarding the practices of arms brokers. Such a treaty would ensure that middlemen cannot move weapons from conflict to areas free of conflict for fear of prosecution.

\section{Reference}

Abdel-Fatau, M. (2002), "Small arms: a time bomb under West Africa's democratization process", Brown Journal of World Affairs 9: 1.

Adibe, J. (2012), “Boko Haram: One sect, conflicting narratives.” African Renaissance, 9(1).

Alozieuwa, S.H.O (2012), contends Theories on Nigeria's Security Challenge in the Era of Boko Haram Insurgency. Peace and Conflict Review. Volume 7, Issue 1

http://www.review.upeace.org/index.cfm?opcion=0\&ejemplar=24\&entrada=128

Anyadike, I. and Nkechi, O. (2013), Boko Haram and National Security Challenges in Nigeria; Causes and Solutions: Journal of Economics and Sustainable Development Vol.4, No.5, pp 2222-2855

Army seizes petrol tanker loaded with arms,' The Nation, 14 July 2013.

Background to the Nigerian Civil Service, Office of the Head of Service of the Federation. Retrieved 2015 January.

Badmus I. A. (2009), "Managing Arms in Peace Processes: ECOWAS and the West African Civil Conflicts. WP/CEAUP/2009 www.Africanos.eu

Badmus I. A. (2009), "Managing Arms in Peace Processes: ECOWAS and the West African Civil Conflicts. WP/CEAUP/2009 www.Africanos.eu

Bah Alhaji, (2004), "Implementing the ECOWAS Moratorium in Post-war Sierra Leone. Prepared for the working group of the Peace building coordination committee in support of the peace building and Human security:

Development of policy capacity of the voluntary sector project.

BBC (2014), Nigeria's Boko Haram puts Maiduguri under 'siege'12 September,2014

Beetseh, K. (2010),Civil Service Reforms in Nigerian and Challenges of National development. Journal of Arts and Contemporary Society. Vol. 2. December, 2010

Bekoe, D. (2011), Nigeria's 2011 Elections: Best Run, but Most Violent by (Peace Brief, August 2011) Washington: UNO Publication

Berkowitz, Leonard (1969), The frustration-aggression hypothesis revisited, in: Berokowitz (ed.), Roots of aggression, Atherton Press, New York

Brock, J. (2012), "Untold Story of how Boko Haram bombed UN House," The Nation Wednesday, February 1, pp 23.

Daniel, M. and Gbenga, A. (2014) Facing a Crackdown by Nigeria's Army in Cities, Islamist militants are targeting villages in the northeast. Daily trust, 14 February, P.13

Edward, Laurence and Rachael S. (2002) in Sears, Nathan A. (2012), "Controlling Small Arms and Light Weapons Proliferation: The Potential of the Arms Trade Treaty. Norman Paterson School of international Affairs, Carleton University"

Egburonu, S, (2012), "Tension as groups flee over Boko-Haram Threats", The Nation on Sunday, January 29, pp 20-22.

Ekereke, A. S. (2013) "The Effects of Boko Haram Insurgency and the School System; A Case Study of Selected States in Northern Nigeria" Volume 2013, Article ID sjsa-137, 5

Eme, O. . (2009) "Ethno-Religious Identities in Nigeria: Implications for Good Governance in Nigeria." A Paper submitted to the Editor-in-Chief of a Book Project on Islam and Governance in Nigeria.

Eme, O. I. (2004) “Insecurity Question in Nigeria: A Thematic Exposition," The Academy, Vol. 4, No. 4, (July) pp. 89.

Emeka, T. N. (2011) G. International Policy Journal globalization and Terrorism in Nigeria 2 Terrorism in Nigeria 
Freedom C. $O$ (2013) Porous Borders and Boko Haram's Arms Smuggling Operations in Nigeria. Aljazeera center of studies

Freedom, C. O. (2012), "Small Arms and Light Weapons Proliferation and Human Security in Nigeria" Published by the African Centre for the Constructive Resolution of Dispute (ACCORD)

James I. (1989), 'Lake Chad as an Instrument of International Co-operation,' in A.I Asiwaju and P. 0 Adeniyi (eds.), Borderlands in Africa: A Multidisciplinary and Comparative Focus on Nigeria and West Africa (Lagos: University of Lagos Press) pp.309-311.

Jennifer M. H. and Jonas, H. (2007) Small Arms, Armed Violence, and Insecurity in Nigeria: The Niger Delta in Perspective

Kwaru, M. I. (2013), 'Boko Haram: Senior Customs Personnel arrested over arms importation in Borno,' Peoples Daily, 29 May.

M. Spencer (2007), 'Border and State Insecurity,' in J.F Forest (ed) Countering Terrorism and Insurgency in the 21st Century: International Perspectives, Vol. 2 (Westport: Praeger Security International) p.110.

Musa,S.(2013), 'Border Security, Arms Proliferation and Terrorism in Nigeria,' Sahara Reporters, 20 April, http://saharareporters.com/article/border-security-arms-proliferation-and-terrorism-nigeria-lt-col-sagirmusa?goback=.gde_4451300_member_234179302.

Okumu, W (2010), 'Africa's Problematic Borderlines,' Africa.org, February/March, p.22.

Okwe, J. (2013), 'Ex-militant, 4 Others Arrested for Arms Supply to Boko Haram,' Thisday, 27 July, p.57

Onuoha, F. C. (2011), 'Small Arms and Light Weapons Proliferation and Human Security in Nigeria,' Conflict Trends, 1, pp. 50-56. 